\title{
Fertility intention and use of contraception among women living with the human immunodeficiency virus in Oromia Region, Ethiopia
}

\author{
Kebogile Mokwena* and Yenealem Reta Bogale ${ }^{\mathrm{b}}$ \\ aDepartment of Public Health, Sefako Makgatho Health Sciences University, Pretoria, South Africa \\ bDepartment of Health Studies, University of South Africa, Pretoria, South Africa \\ *Corresponding author, email: kebogilemokwena@embanet.com
}

Background: The human immunodeficiency virus (HIV) epidemic resulted in decreased fertility among HIV-positive women, who did not want to transmit the virus to their unborn children. With the availability of antiretroviral therapy that suppresses viral load, HIV-infected women live normal lives and even acknowledge the desire and intention to have children, a factor that is rarely acknowledged in antiretroviral therapy (ART) clinic services. This study examined fertility intentions and contraception use among a sample of women attending an ART clinic in Oromia Region, Ethiopia.

Methods: A quantitative, cross-sectional and descriptive design was used on a sample of 362 HIV-positive women. Data were collected using a researcher-administered questionnaire.

Results: The ages of the participants ranged from 18 to 49 years and most were between the ages of 23 and 32 . A desire and intention to fall pregnant was reported by $46.6 \%(n=158)$ of the participants. A total of $114(35.5 \%)$ had given birth after they were diagnosed with HIV and $4 \%$ were pregnant at the time of the study. Of the study participants who wanted to have children, $60.7 \%(n=82)$ planned to have a child within two years. In the period before they were diagnosed with HIV, most participants used injectable contraceptives but this changed to using the condom after they were diagnosed with HIV.

Conclusion: The high number of women who have both the desire and intention to have children among this sample of HIVpositive women requires that reproductive health services need to include family planning as an essential component of reproductive health services. The change to using the condom as a contraceptive method indicates the positive impact of health promotion received at ART clinic.

Keywords: contraception use, fertility intention, HIV infections, pregnant women

\begin{abstract}
Introduction
The sub-Saharan Africa region remains most affected by HIV, accounting for an estimated $67 \%$ of the global prevalence of infections, and women of reproductive age account for the majority of the people living with HIV. Compared with other African countries, the overall HIV prevalence in Ethiopia has remained, being reported at $1.14 \%$ nationally and even lower in rural areas (WHO Regional Office for Africa, 2014). However, as with other African countries, women disproportionately account for higher prevalence of the HIV-positive population. ${ }^{1-3}$
\end{abstract}

Reductions in births among HIV-infected women occurred because of reduced intention to have children. ${ }^{4}$ However, from the early 2000 s, the desire to have children among these women showed increasing trends because of the improved quality of life and survival following the commencement of anti-retroviral treatment and tailor-made reproductive health services. ${ }^{5}$ In fact, the availability of ART seems to have increased HIV-positive women's desire and intention to have children to levels approaching those of the general population. ${ }^{6}$

A focus on reproductive health has been credited to the global successes achieved in the improvement of maternal and child health services in the past decade. ${ }^{7}$ However, this success needs to be enhanced in the face of renewed desire to have children by People Living With HIV and AIDS (PLWHA). This therefore requires significant investments in sexual and reproductive health services to cater for the needs of this group of women. In practice, there are limited reproductive health services for HIV-positive people, and the few that are available are limited to prevention of pregnancy.
Among reasons cited for lack of these services is that health facilities are not ready to discuss fertility desires for HIV-positive women, partly due to limited human and financial resources. ${ }^{8}$

The intention to have children among African HIV-positive women may be influenced by, among others, the fact that in many African societies a woman's identity, position and status is influenced by the ability to bear children. Furthermore, this ability affects her social standing, individual recognition, partnership stability and, through these conventions, her financial security. ${ }^{9}$ In actuality, among African populations, failure to have children has been associated with negative social consequences, including domestic violence..$^{10,11}$

In sub-Saharan Africa, where the HIV prevalence is highest, the traditional roles of women, the socio-cultural importance of motherhood, and a woman's partner's desire for children, independent of her own desire, may be significant predictors of pregnancy and childbirth. The infection rate among pregnant women in subSaharan Africa is also alarmingly high, where $90 \%$ of global new child infections occur through mother-to-child transmission (MTCT). ${ }^{12}$

The fertility intentions of HIV-infected women are affected by the same community and cultural norms as those of uninfected women, and are generally similar to those of uninfected women. However, these intentions are seldom acknowledged in the planning and provision of reproductive health services. ${ }^{13}$

A significant factor that prevented women living with HIV and AIDS (WLHA) from fulfilling their desire for motherhood was the 
fear of transmitting infection to the child, which has changed since the successful implementation of Prevention of Mother-To-ChildTransmission programme. ${ }^{14}$ For many women, the desire to have children is determined by social and personal expectations, with women who desire to have children being more likely to be married or to have a partner. Other studies found that for HIVpositive people, reproductive potential, demographic characteristics, ethnicity, marital status, fertility status and partner's HIV status influenced the desire for a child, whereas the person's own clinical condition in relation to HIV had little or no impact. ${ }^{15,16}$

With a population of about 100658 562, Ethiopia is the second most populous country in Africa. The fertility rate in rural Ethiopia is nearly two and half times greater than in urban centres (6.0 versus 2.4). Among the nine regional states under the Federal Government of Ethiopia, Oromia Region has the highest fertility rate of about 6.2 children per woman, contrasting with Addis Ababa, with a below-replacement level of fertility of 1.4 children per woman (Ethiopian Demographic Health Survey, 2011). ${ }^{17}$ Oromia is also the largest population of the nine regions, which is estimated at 28.8 million. ${ }^{18}$

Contraceptive use in Ethiopia is very low, ${ }^{19,20}$ with only $14.7 \%$ of married women nationally, and $13.6 \%$ in Oromia Regional State using any method of contraception. ${ }^{17}$ Concerns have been raised about uncontrolled fertility, which has adversely influenced the socio-economic, demographic and environmental situations in the country. ${ }^{21}$ Promotion of the use of contraception has been identified as an effective tool for this situation. A high level of education, being married, and current use of ART have been positively associated with the use of contraception. ${ }^{22}$

Literature has indicated that, age, marital status, level of education and the number of children significantly influenced the desire for children among HIV-infected individuals. ${ }^{23,24}$ On the contrary, the disclosure of one's seropositive status to the partner/spouse is associated with a lesser desire for children. Concerns expressed by women about the possibility of bearing HIV-positive children include the impact of pregnancy on their own health, and what will happen to their children in the event of their death. ${ }^{23}$ On the other hand, the high social value placed on children has a significant influence towards the desire to have children among many African women, ${ }^{24,25}$ including those that are HIV positive. Childbearing is also a human rights issue that should not be denied to HIV-positive people. ${ }^{26}$

The fertility intention and use of contraception of HIV-positive women are influenced by their culture, their level of education, their socio-economic status, and the condition of their health. ${ }^{13,27}$ Despite the growing importance of fertility considerations and options for HIV-infected women in Ethiopia, little is known about their actual fertility intentions and utilisation of contraception, hence this study.

The objectives of the study were to examine the fertility intentions of a sample of women living with HIV/AIDS, and to describe the utilisation of contraception methods used by this sample.

\section{Methods}

This cross-sectional quantitative study was conducted among women who attended the HIV clinic in Adama Hospital Medical College, in Oromia Region, Ethiopia, which is a governmentowned hospital that provides ART services at no cost to the patient. The population consisted of an estimated 4000 HIVpositive women who receive ART services at the ART clinic every month. A non-probability sampling technique was implemented to select a minimum sample of convenience of 368 participants, which was obtained using the Raosoft sample size calculator.

The women were approached by the researcher or research assistants while awaiting their turn to get services at the clinic. The purpose of the study was briefly explained and they were requested to participate. Those who agreed were given more details and invited to be interviewed in private.

Data were collected by the use of a self-developed questionnaire, which was translated from English to the local Amharic language. Preparation for data collection included the training of two data collectors on research methods, ethics and the use of the data collection tool.

SPSS $^{\circledR}$ version 20 (IBM Corp, Armonk, NY, USA) was used to analyse the data for frequency distributions and measures of central tendency, and logistic regression was employed to test for associations between variables, using a $5 \%$ statistical level of significance

The study obtained ethics approval from the Ethics Committee of the Department of Health Studies at UNISA. Permission to conduct the study was granted by the Oromia region Health Bureau, as well as the board and management of Adama Hospital Medical College. Informed consent was obtained from each participant before administering the interview schedule.

\section{Results}

Of the 368 eligible clients sampled in the ART treatment clinic during the study period, 362 agreed to participate in the study, giving a response rate of $98.4 \%$. The age range of the participants was 18 to 49 years. Some $30.4 \%(n=110)$ of the respondents were in the age group $28-32$, and $27.6 \%(n=100)$ were between 23 and 27 years old.

The majority of the respondents $(71.8 \% ; n=260)$ were Orthodox Christians. The Oromo ethnicity was $44.2 \%(n=160)$ and $30.9 \%$ $(n=112)$ were Amharas. A significant number of the respondents (21.5\%; $n=78)$ were illiterate. More than half of them $(63.5 \%$, $n=230)$ were married, while $16.3 \%(n=59)$ were divorced and $13 \%(n=47)$ were widowed. The sample consisted of $27.07 \%$ ( $n=98)$ housewives while $20.9 \%(n=76)$ were daily labourers. A significant number $(30.7 \% ; n=111)$ did not have a monthly income, whereas $20.7 \%(n=75)$ of the respondents' incomes were within the range 201-400 ETB (Ethiopian Birr), and 19.3\% $(n=70)$ of the study participants' incomes were between 401 and 600 ETB. Birr. Table 1 shows the socio-demographic characteristics of the participants.

\section{Gravida history and fertility intention}

Table 2 shows the frequency distributions of fertility intentions of the 172 participants who reported the desire to have children in the future. The majority of the participants $(88.7 \% ; n=321)$ had previously given birth, with $44.2 \%(n=142)$ of them having had $2-3$ live births, and $38.3 \%(n=107)$ had given live birth to one child. Some $35.5 \%(n=114)$ had given birth after they were diagnosed with HIV. The majority $(70.3 \% ; n=232)$ had planned their last pregnancy, whereas $29.7 \%(n=98)$ had had an unplanned last pregnancy. 
Table 1: Demographics of the participants

\begin{tabular}{|c|c|}
\hline Variables & Frequency and \% \\
\hline \multicolumn{2}{|l|}{ Age groups } \\
\hline $18-22$ & $17(4.7)$ \\
\hline $23-27$ & $100(27.6)$ \\
\hline $28-32$ & $110(30.4)$ \\
\hline $33-37$ & $64(17.7)$ \\
\hline $38-42$ & $52(14.4)$ \\
\hline $43-47$ & $19(5.2)$ \\
\hline Total & 362 \\
\hline \multicolumn{2}{|l|}{ Religion } \\
\hline Orthodox & $260(71.8)$ \\
\hline Catholic & $6(1.7)$ \\
\hline Muslim & $29(10.8)$ \\
\hline Protestant & $54(14.9)$ \\
\hline Other & $3(0.8)$ \\
\hline Total & 362 \\
\hline \multicolumn{2}{|l|}{ Ethnicity } \\
\hline Oromo & $160(44.2)$ \\
\hline Amhara & $112(30.9)$ \\
\hline Gurage & $51(14.1)$ \\
\hline Tigire & $33(9.1)$ \\
\hline Other & $6(1.7)$ \\
\hline Total & 362 \\
\hline \multicolumn{2}{|l|}{ Marital status } \\
\hline Married & $230(63.5)$ \\
\hline Single & $20(5.5)$ \\
\hline Widowed & $47(13.0)$ \\
\hline Divorced & $59(16.3)$ \\
\hline Unmarried & $6(1.7)$ \\
\hline Total & 362 \\
\hline
\end{tabular}

At the time of data collection $4 \%(n=14)$ of the study participants were pregnant, whereas $96 \%(n=348)$ were not pregnant. The proportion of those that had future fertility desires was $46.6 \%$ $(n=158)$ and $47.2 \%(n=160)$ had no future fertility intention. Of the study participants who wanted to have children, $31.1 \%$ $(n=42)$ of them planned to have a child within a period of less than two years, $29.6 \%(n=40)$ of the women wanted to have children two years later, and $8.15 \%(n=11)$ were uncertain about when they would like to have children.

Ensuring the continuation of posterity was the most frequently stated reason for wanting to have children, with attempt to hide the HIV-positive status (in their communities being pregnant was perceived to confirm negative HIV status, as HIV-positive women were discouraged from falling pregnant) and the partner wanting a child less frequently stated.

Of the women aged $23-27$ years, $37.7 \%(n=58)$ stated their fertility intention, and $32.7 \%(n=55)$ of the women in the age group of 28-32 have a fertility intention. Of those with fertility intentions, $74.4 \%(n=120)$ were Orthodox in religious affiliation.
Table 2: Frequency distributions of fertility intentions

\begin{tabular}{|c|c|}
\hline Variables & Frequency/number (\%) \\
\hline \multicolumn{2}{|l|}{ Ever given birth } \\
\hline Yes & $321(88.7)$ \\
\hline No & $41(11.3)$ \\
\hline Total & 362 \\
\hline \multicolumn{2}{|l|}{ Number of children } \\
\hline 1 & $8(2.5)$ \\
\hline 2 & $111(34.6)$ \\
\hline 3 & $91(28.3)$ \\
\hline $4+$ & $111(34.6)$ \\
\hline Total & 321 \\
\hline \multicolumn{2}{|l|}{ Given birth after learning of HIV-positive status } \\
\hline Yes & $114(35.5)$ \\
\hline No & $207(64.5)$ \\
\hline Total & 321 \\
\hline \multicolumn{2}{|l|}{ Desire to have children in the future } \\
\hline Yes & $172(47.5)$ \\
\hline No & $190(52.5)$ \\
\hline Total & 362 \\
\hline \multicolumn{2}{|l|}{ Number of intended children in the future } \\
\hline None & $25(6.9)$ \\
\hline One & $33(9.1)$ \\
\hline Two & $73(20.2)$ \\
\hline Three & $35(9.7)$ \\
\hline More than 3 & $6(1.7)$ \\
\hline Total & 172 \\
\hline \multicolumn{2}{|l|}{ Reason for desire to give birth } \\
\hline To hide HIV-positive status from people & $9(5.2)$ \\
\hline To avoid stigma and discrimination & $13(7.6)$ \\
\hline To replace my heredity & $118(68.6)$ \\
\hline My partner wants a child & $9(5.2)$ \\
\hline Other & $23(13.4)$ \\
\hline Total & 172 \\
\hline
\end{tabular}

Table 3: Fertility intentions with the socio-demographic variables

\begin{tabular}{|c|c|c|c|c|}
\hline Variables & \multicolumn{2}{|c|}{$\begin{array}{l}\text { Fertility intention } \\
\text { Yes }\end{array}$} & OR & $p$-value \\
\hline \multicolumn{5}{|l|}{ Age groups } \\
\hline $38-42$ & $13(7.6)$ & $39(20.5)$ & $0.24(0.11-0.54)$ & 0.00 \\
\hline \multicolumn{5}{|c|}{ Educational level } \\
\hline $\begin{array}{l}\text { Secondary } \\
\text { education }\end{array}$ & $30(17.4)$ & $12(6.6)$ & $2.85(1.22-6.75)$ & 0.01 \\
\hline \multicolumn{5}{|l|}{ Ethnicity } \\
\hline Gurage & $35(20.3)$ & $16(8.4)$ & $2.30(1.12-4.74)$ & 0.02 \\
\hline \multicolumn{5}{|l|}{ Marital status } \\
\hline Widowed & $5(2.9)$ & $42(22.1)$ & $0.11(0.04-0.29)$ & 0.00 \\
\hline \multicolumn{5}{|c|}{ Monthly income (ETB) } \\
\hline $401-600$ & $24(14.0)$ & $46(24.2)$ & $0.49(0.25-0.96)$ & 0.03 \\
\hline
\end{tabular}


Of the illiterate participants, $25 \%(n=43)$ had fertility intentions. A significant proportion of the married women $(70.9 \%, n=120)$ had fertility intentions, and $33.1 \%(n=57)$ of the women with no income also had fertility intentions. The fertility intentions with significant values are reflected in Table 3.

\section{Contraception use}

A significant proportion of the participants $(47.5 \%, n=172)$ had fertility intention, and $65.7 \%(n=113)$ of these were using contraception before they were diagnosed with HIV, with injectable contraceptives being the most frequently used. Of the total of 172 of the study participants who stated their fertility intention, 68\% ( $n=117)$ reported using contraceptives after HIV

Table 4: Fertility Intention

\begin{tabular}{|c|c|c|c|c|}
\hline \multirow[t]{2}{*}{ Variables } & \multicolumn{2}{|c|}{ Fertility intention } & \multirow[t]{2}{*}{ Crude OR } & \multirow[t]{2}{*}{$p$-value } \\
\hline & Yes & No & & \\
\hline \multicolumn{5}{|c|}{ Types of contraceptive } \\
\hline Condom & $30(18.8)$ & $11(7.7)$ & $\begin{array}{c}3.52 \\
(1.58-7.97)\end{array}$ & 0.00 \\
\hline Pills & $21(13.1)$ & $44(30.8)$ & $\begin{array}{c}0.38 \\
(0.20-0.73)\end{array}$ & 0.01 \\
\hline Injectable & $87(52.5)$ & $70(48.9)$ & $\begin{array}{c}0.50 \\
(0.28-0.91)\end{array}$ & 0.02 \\
\hline \multicolumn{5}{|c|}{ Ever used FP after HIV-positive status known? } \\
\hline Yes & $117(68.0)$ & $104(54.7)$ & $\begin{array}{c}0.57 \\
(0.36-0.89)\end{array}$ & 0.01 \\
\hline No & $55(32.0)$ & $86(45.3)$ & & \\
\hline Total & 172 & 190 & & \\
\hline \multicolumn{5}{|c|}{ Discussed reproductive health topics with counsellors? } \\
\hline Yes & $133(77.3)$ & $129(67.9)$ & $\begin{array}{c}0.62 \\
(0.38-1.02)\end{array}$ & 0.05 \\
\hline No & $39(22.7)$ & $61(32.1)$ & & \\
\hline \multicolumn{5}{|l|}{ Topics to discuss } \\
\hline $\begin{array}{l}\text { Current } \\
\text { contraceptive } \\
\text { use }\end{array}$ & $83(23.9)$ & $104(25.9)$ & $\begin{array}{c}2.51 \\
(1.38-4.56)\end{array}$ & 0.00 \\
\hline MTCT of HIV & $91(26.1)$ & $116(28.9)$ & $\begin{array}{c}4.12 \\
(2.00-8.62)\end{array}$ & 0.00 \\
\hline $\begin{array}{l}\text { Condom } \\
\text { utilisation }\end{array}$ & $85(24.4)$ & $107(26.7)$ & $\begin{array}{c}2.75 \\
(1.48-5.11)\end{array}$ & 0.00 \\
\hline \multicolumn{5}{|c|}{ Discussed FP with health providers? } \\
\hline Yes & $140(81.4)$ & $128(67.4)$ & $\begin{array}{c}0.47 \\
(0.28-0.79)\end{array}$ & 0.00 \\
\hline No & $32(18.6)$ & $62(92.6)$ & & \\
\hline \multicolumn{5}{|l|}{ Methods used } \\
\hline Abstinence & $75(14.2)$ & $86(15.2)$ & $\begin{array}{c}1.77 \\
(1.05-3.01)\end{array}$ & 0.03 \\
\hline Condom & $112(21.3)$ & $119(21.0)$ & $\begin{array}{c}3.31 \\
(1.41-7.92)\end{array}$ & 0.00 \\
\hline Pills & $72(13.7)$ & $83(14.6)$ & $\begin{array}{c}1.74 \\
(1.03-2.94)\end{array}$ & 0.03 \\
\hline $\begin{array}{l}\text { Tubal } \\
\text { ligation }\end{array}$ & $56(10.6)$ & $70(12.3)$ & $\begin{array}{c}0.55 \\
(0.33-0.92)\end{array}$ & 0.02 \\
\hline \multicolumn{5}{|c|}{ Do you intend to use contraception methods in future? } \\
\hline Yes & $39(69.0)$ & $10(14.7)$ & $\begin{array}{c}16.16 \\
(6.00-44.91)\end{array}$ & 0.00 \\
\hline No & $14(31.0)$ & $58(52.3)$ & & \\
\hline
\end{tabular}

diagnosis. At the time of the study, $58.2 \%(n=96)$ of the women who reported using contraceptives had fertility intentions. In all, $50 \%$ of the women $(n=48)$ who reported using contraceptives at the time of the study were using injectables and $34.4 \%(n=33)$ were using condoms. Table 4 shows the statistically significant variables associated with fertility intentions.

\section{Discussion}

Globally, health systems often fail to acknowledge the desires of HIV-infected women to have children, and this has resulted in failure to provide appropriate related services for these women. In areas of high HIV prevalence, health services often emphasise antiretroviral therapy (ART) and other health care services, but disregard issues of fertility and childbearing among this group of people. Often the determinants of fertility intentions among HIV-infected women are not known, and inadequate attention is paid to this area of reproductive life of a section of the population.

Studies have linked fertility desire with increased adherence to ART among females, and thus highlight the need to incorporate fertility-related counselling and contraception advice in HIV treatment services. ${ }^{27}$ Because fertility desires may change over time, fertility-related counselling and contraception advice require ongoing assessment and long-term care.

This study showed a high proportion $(47.5 \% ; n=172)$ of HIVpositive women who wished to have children, and this is much higher than the $16 \%$ reported in Uganda, ${ }^{28}$ the $19.2 \%$ in Brazil ${ }^{29}$ and the $25.8 \%$ previously reported by Ogilvie in Canada. ${ }^{6}$ It was, however, consistent with the results reported in Addis Ababa, where $44.7 \%$ of the respondents expressed the desire for children. ${ }^{23}$ This suggests that the desire to have children among HIV-positive women may be higher in Ethiopian communities than in other countries. Interestingly, more HIV-positive women than men reported the desire for children even though they already have children, ${ }^{23}$ which suggests that among African women the desire to have children is a much more complex matter than just the wish to continue posterity.

The results also showed that $43.6 \%(n=75)$ of the participants who wished to have children planned to have children within a period of less than two years, $34.3 \%(n=59)$ wanted to have children over a period exceeding two years, and $20.3 \%(n=35)$ were not specific about when they would want to have children. The reproductive decisions in HIV-positive women are not only affected by their HIV status but depend on different factors, especially not having a child previously, and being married or in a relationship. Large numbers of HIV-positive women with no income, housewives, those that are illiterate, and women in the age group 28-32 years had the intention to fall pregnant. In another study conducted in Canada, being of African origin was a significant predictor of wishing to have children among HIVpositive women, which may explain these findings. ${ }^{24}$

The most prevalent family planning method among the HIVpositive women before their HIV diagnosis was injectables, which changed to condoms after the HIV-positive diagnosis. Similar results of condom use being the preferred contraceptive among HIV-positive women in Kenya were also reported. ${ }^{30}$ The finding that many HIV women in this sample wanted to have children in the near future are similar to a study conducted in Lesotho ${ }^{31}$ and this has significant implications for the transmission of HIV to sexual partners and to newborns. 
The desire to have children in this group of HIV-positive women requires that this factor be integrated into counselling content in the services offered in the ART clinic. This desire does not impact only on their being sero-positive, and therefore the need to consider the risk of HIV transmission to the child, but also the difficulty of combining being a parent with the constraints of their illness. However, considering the high value of childbearing in Ethiopian society, it is recommended that systematic counselling on reproductive options be offered to all ART clinic attendees. This will assist them in making informed reproductive choices rather than taking a risk of transmitting HIV to their partners. ${ }^{32}$ Moreover, there are reports of unmet reproductive counselling needs among HIV-positive women, and health services at health facilities should address this unmet need. ${ }^{33-35}$ Health services should therefore intentionally enquire about, plan and implement reproductive health needs and intentions of HIV-positive women, which will provide a comprehensive service. ${ }^{36}$

\section{Conclusion}

Although most HIV prevention programmes seem to focus on prevention of pregnancy among HIV-positive women, this study has demonstrated that the desire and intention to have children among this group of women cannot be disregarded and ignored. Reproductive health care services in ART clinics need to integrate these desires into reproductive care services. With availability of ART and an increased ability to live a normal life, the desire and intention to have children among HIV-positive women has been invigorated and this needs to be acknowledged and integrated into reproductive health services, as recommended by previous studies. ${ }^{24,37}$

\section{References}

1. Abdool Karim Q, Sibeko S, Baxter C. Preventing HIV Infection in women: a global health imperative. Clin Infect Dis. 2010;50(s3):S122-9. http://dx.doi.org/10.1086/651527

2. Baral S, Beyrer C, Muessig K, et al. Burden of HIV among female sex workers in low-income and middle-income countries: a systematic review and meta-analysis. Lancet Infect Dis. 2012;12(7):538-49. http://dx.doi.org/10.1016/S1473-3099(12)70066-X

3. Dellar RC, Dlamini S, Karim QA. Adolescent girls and young women: key populations for HIV epidemic control. HIV and adolescents: focus on young key populations; 2015. p. 64.

4. Yeatman S. The impact of HIV status and perceived status on fertility desires in rural Malawi. AIDS Behav. 2009;13(S1):12-9. http://dx.doi.org/10.1007/s10461-009-9534-1

5. Myer L, Carter RJ, Katyal M, et al. Impact of antiretroviral therapy on incidence of pregnancy among HIV-infected women in subSaharan Africa: a cohort study. PLoS Med. 2010;7(2):e1000229. http://dx.doi.org/10.1371/journal.pmed.1000229

6. Ogilvie GS, Palepu A, Remple VP, et al. Fertility intentions of women of reproductive age living with HIV in British Columbia, Canada. AIDS. 2007;21:S83-8. http://dx.doi.org/10.1097/01. aids.0000255090.51921.60

7. Mascarenhas MN, Flaxman SR, Boerma T, et al. National, regional, and global trends in infertility prevalence since 1990: a systematic analysis of 277 health surveys. PLoS Med. 2012;9(12):e1001356. http://dx.doi. org/10.1371/journal.pmed.1001356

8. Rossi ADS, Amaral E, Makuch MY. Access of people living with HIV to infertility services: perspective of Brazilian healthcare professionals. AIDS Care. 2011;23(10):1329-35. http://dx.doi.org/10.1080/0954012 1.2011 .564113

9. OmbeletW, Cooke I, Dyer S, et al. Infertility and the provision of infertility medical services in developing countries. Hum Reprod Update. 2008;14(6):605-21. http://dx.doi.org/10.1093/humupd/dmn042

10. Ola TM. The socio-cultural perception and implications of childlessness among men and women in an urban area, Southwest Nigeria. J Soc Sci. 2009;21(3):205-9.

11. Dhont N, van de Wijgert J, Coene G, et al. 'Mama and papa nothing': living with infertility among an urban population in Kigali, Rwanda. Hum Reprod. 2011;26(3):623-9. http://dx.doi.org/10.1093/humrep/deq373
12. World Health Organization. Sexual and reproductive health of women living with HIV/AIDS: guidelines on care, treatment and support for women living with HIV/AIDS and their children in resource-constrained settings. Geneva: World Health Organization; 2006.

13. Cooper D, Harries J, Myer L, et al. "Life is still going on": reproductive intentions among HIV-positive women and men in South Africa. Soc Sci Med. 2007;65(2):274-83. http://dx.doi.org/10.1016/j. socscimed.2007.03.019

14. Liamputtong P. Women, motherhood, and living with HIV/ AIDS: an introduction. In: Women, motherhood and living with HIV/AIDS. Dordrecht: Springer, Netherlands; 2013. p. 1-24. http://dx.doi.org/10.1007/978-94-007-5887-2

15. Heard I, Sitta Rémi. Reproductive choice in men and women living with HIV: evidence from a large representative sample of outpatients attending French hospitals (ANRS-EN12-VESPA Study). AIDS. 2007;21(suppl 1):S77-82. http://dx.doi.org/10.1097/01. aids.0000255089.44297.6f

16. Macro ORC. Central Statistical Agency: Ethiopia Demographic and Health Survey 2005. Calverton (MD): ORC Macro; 2006.

17. Macro ORC, Measure DHS. Ethiopia Demographic and Health Survey, 2011: preliminary report. Addis Ababa: Central Statistical Agency; 2011.

18. Bekele A, Fleming K, Habtamu Z, et al. The association of TB with HIV infection in Oromia Regional National State, Ethiopia in 2006/7. Ethiop J Health Dev. 2009;23(1):63-7.

19. Assefa H, Tekleab M, Misganaw F. Family planning. In: Kloos H, editor. Ethiopia in epidemiology and ecology of health and disease in Ethiopia. Addis Ababa: Shama Books; 2006. p. 2-3.

20. Mekonnen W, Worku A. Determinants of low family planning use and high unmet need in Butajira District, South Central Ethiopia. Reprod Health. 2011;8(1):1.

21. Alene GD, Worku A. Estimation of the total fertility rates and proximate determinants of fertility in North and South Gondar zones, Northwest Ethiopia: an application of the Bongaarts' model. Ethiop J Health Dev. 2009;23(1):1-8

22. Andia I, Kaida A, Maier M, et al. Highly active antiretroviral therapy and increased use of contraceptives among HIVpositive women during expanding access to antiretroviral therapy in Mbarara, Uganda. Am J Pub Health. 2009;99(2):340-7. http://dx.doi.org/10.2105/AJPH.2007.129528

23. Tamene W, Fantahun M. Fertility desire and family-planning demand among HIV-positive women and men undergoing antiretroviral treatment in Addis Ababa, Ethiopia. Afr J AIDS Res. 2007;6(3):223-7. http://dx.doi.org/10.2989/16085900709490418

24. Loutfy MR, Hart TA, Mohammed SS, et al. Fertility desires and intentions of HIV-positive women of reproductive age in Ontario Canada: a cross-sectional study. PLoS ONE. 2009;4(12):e7925. http://dx.doi.org/10.1371/journal.pone.0007925

25. Peltzer K, Chao LW, Dana P. Family planning among HIV positive and negative prevention of mother to child transmission (PMTCT) clients in a resource poor setting in South Africa. AIDS Behav. 2009;13(5):973-9. http://dx.doi.org/10.1007/s10461-008-9365-5

26. Gruskin S, Ferguson L, O'Malley J. Ensuring sexual and reproductive healthforpeopleliving with HIV:anoverview of key human rights, policy and health systems issues. Reprod Health Matters. 2007;15(29):4-26. http://dx.doi.org/10.1016/S0968-8080(07)29028-7

27. Myer L, Morroni C, Rebe K. Prevalence and determinants of fertility intentions of HIV-infected women and men receiving antiretroviral therapy in South Africa. AIDS Patient Care STDS. 2007;21(4):278-85. http://dx.doi.org/10.1089/apc.2006.0108

28. Nakayiwa S, Abang B, Packel L, et al. Desire for children and pregnancy risk behavior among HIV-infected men and women in Uganda. AIDS Behav. 2006;10(S1):95-104. http://dx.doi.org/10.1007/s10461-0069126-2

29. Paiva V, Santos N, França-Junior I, et al. Desire to have children: gender and reproductive rights of men and women living with HIV: a challenge to health care in Brazil. AIDS Patient Care STDS. 2007;21(4):268-77. http://dx.doi.org/10.1089/apc.2006.0129

30. Mutiso SM, Kinuthia J, Qureshi Z. Contraceptive use among HIV infected women attending Comprehensive Care Centre. East Africa Med J. 2008;85(4):171-7. 
31. Adair T. Unmet need for contraception among HIV-positive women in Lesotho and implications for mother-to-child transmission. J Biosoc Sci. 2009;41(02):269-78. http://dx.doi.org/10.1017/ S0021932008003076

32. Kirunda I, Livesley N, Zainab A, et al. Strategies used by facilities in Uganda to integrate family planning into HIV care: what works and what doesn't. Afr J Reprod Health. 2010;14(4):149-50.

33. Craft SM, Delaney RO, Bautista DT. Pregnancy decisions among women with HIV. AIDS Behav. 2007;11(6):927-35. http://dx.doi. org/10.1007/s10461-007-9219-6

34. Stanwood N, Cohn S, Heiser J, et al. Contraception and fertility plans in a cohort of HIV positive women in care. Contraception. 2007;75:294-8. http://dx.doi.org/10.1016/j.contraception.2006.12.012

35. Kikuchi K, Wakasugi N, Poudel, KC, et al. High rate of unintended pregnancies after knowing of HIV infection among HIV positive women under antiretroviral treatment in Kigali, Rwanda. BioSci Trends. 2011;5(6):255-63. http://dx.doi.org/10.5582/bst.2011. v5.6.255

36. Finocchario-Kessler S, Dariotis JK, Sweat MD, et al. Do HIV-infected womenwanttodiscussreproductive planswith providers, andarethose conversations occurring? AIDS Patient Care STDS. 2010;24(5):317-23. http://dx.doi.org/10.1089/apc.2009.0293

37. Cooper D, Moodley J, Zweigenthal V, et al. Fertility intentions and reproductive health care needs of people living with HIV in Cape Town, South Africa: implications for integrating reproductive health and HIV care services. AIDS Behav. 2009;13(S1):38-46. http://dx.doi.org/10.1007/s10461-009-9550-1

Received: 12-08-2016 Accepted: 24-10-2016 